\title{
Correction to: Quasirealism as semantic dispensability
}

\author{
Derek Baker ${ }^{1}$ (iD
}

\section{Correction to:}

\section{Philos Stud}

https://doi.org/10.1007/s11098-020-01556-2

In the original publication of the article, the Acknowledgement section was not included. The section is given below.

Acknowledgement Research in this paper was partially supported by research leave from Lingnan University, and was substantially supported by a General Research Fund grant from the Research Grants Council of Hong Kong SAR, China (LU13601218). Thanks to Tristram McPherson, Dan Waxman, and the two anonymous referees, all of whom provided exceptional criticism, objections, and positive suggestions, without which this would be a much weaker paper.

Publisher's Note Springer Nature remains neutral with regard to jurisdictional claims in published maps and institutional affiliations.

The original article can be found online at https://doi.org/10.1007/s11098-020-01556-2.

Derek Baker

derekbaker@ln.edu.hk

1 Department of Philosophy, Lingnan University, 8 Castle Peak Road, Tuen Mun, NT, Hong Kong SAR 